\title{
3-4-2ＬS-120 ディスク
}

\section{平 中 弘 - ${ }^{+}$}

\section{1. まえがき}

従来の 3.5 インチフロッピーと同様に手軽なディス クで画像, 音声を扱えるマルチメディアドライブが待 望されていた。当社は, ORT, イメーション(旧 3 M)，コンパックと共同で従来と同じ 3.5 インチ標準 ディスクの書き換え, 再生ができる「完全下位互換性 機能」とフォーマット容量 $120 \mathrm{MB}$ のフロッピー, LS-120 ディスクの書き換え，再生ができる $120 \mathrm{MB}$ FDD，「LS-120 ドライブ」を 1995 年開発し，1996 年 5 月より量産販売を開始した ${ }^{11}$. 完全下位互換性に したのは，標準パソコンに大容量 FDD を搭載するた めの必須の条件と考元たからである. 写真 1 に LS120 ドライブを示す。

\section{2. 高容量化の技術}

\subsection{FDD での高容量化}

記録容量の大容量化は，狭トラック化と線記録密度 の向上にある.図 1 に, これまで開発されてきた FDD のトラックピッチ（TPI：1インチのトラック 数/Track Per Inch) と線記録密度（BPI：1インチ あたりの記録密度/Bits Per Inch）の関係を示す。狭 トラック化を実現するには，磁気へッドの高精度のト ラック加工技術が要求されるとともに, 微細トラック 位置制御機構が必要である。線記録密度の向上には， ヘッドとメディアの選択とその良好な接触状態の実現 が必要である。

トラック位置制御はサーボ技術といわれ，

・光サーボ方式 ${ }^{2)}$

・セクタサーボ方式

・埋め込みサーボ方式

に大別できる.

セクタサーボは，ハードディスクドライブに採用さ れている方式であり，セクタ間にオントラックさせる ためのサーボパターンを配置する。埋め込みサーボ

†松下寿電子工業株式会社 情報機器開発センター

“3-4-2 LS-120 Diskettes”by Kouichi Hiranaka (Information Equipment Development Center, Matsushita-Kotobuki Electronics Ind., Ltd., Ehime)

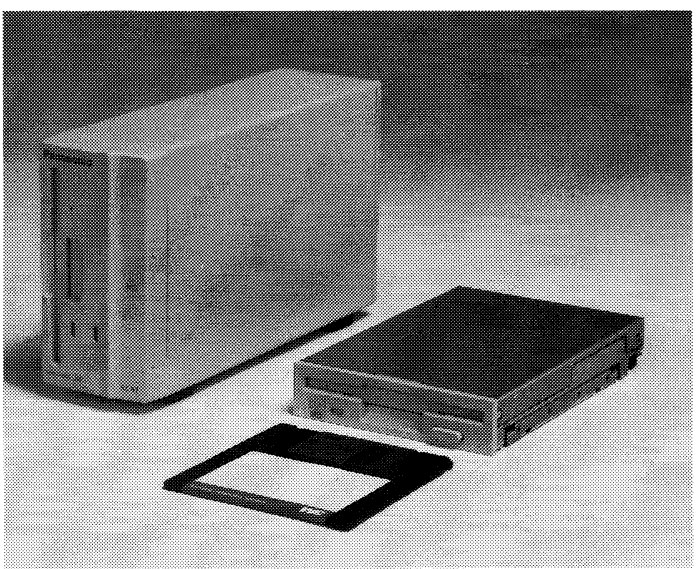

写真 1 LS-120 ディスクドライブ

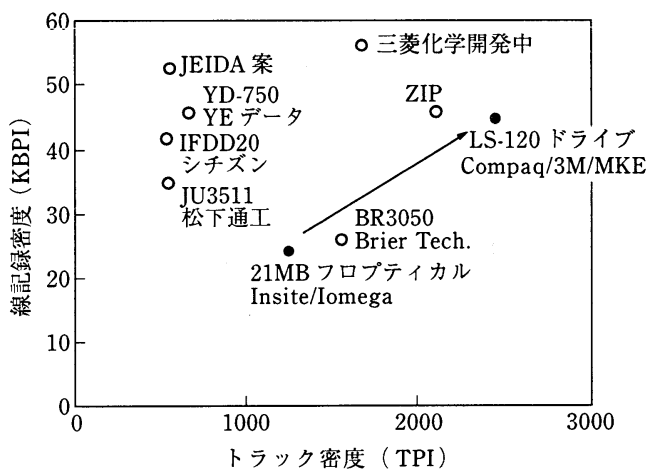

図 1 大容量 FDD の高密度化

は，磁性層の深層にサーボ情報を書込む方式である． LS-120 ドライブでは, フロプティカルと同様に連続 光サーボを採用した，連続サーボの場合には，ディス クの偏芯許容性を拡大でき, 高精度トラック位置制御 を行うことが可能となる。

\section{2 連続光サーボ技術}

光源にレーザダイオードを用い, ホログラム光学素 子 (HOE)により光サーボ信号を生成し，トラック位 置検出を行う．図 2 に連続光サーボ技術の原理図を示 す。その特徴は, 3.5 インチ標準ディスクのサイド 0 面に, 同心円状に幅 $2.2 \mu \mathrm{m}$, 長さ $42 \mu \mathrm{m}$ (最内周) 


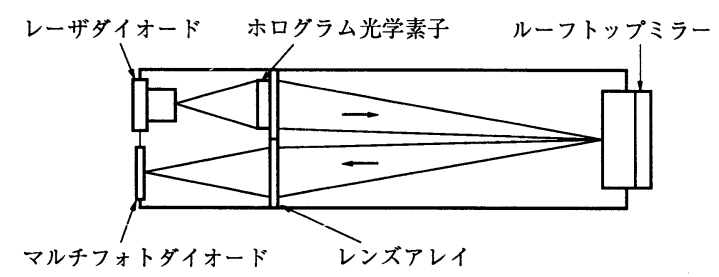

(a) 平面図

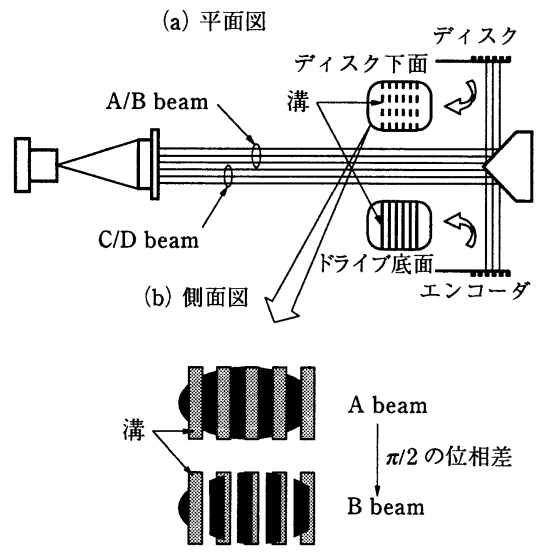

(c) ディスク面搪大図

図 2 LS-120 光サーボ原理図

$\sim 72 \mu \mathrm{m}$ (最外周)の長方形の溝を形成したディスクの 構造にある.このディスクのサイド 0 面に光を照射 し, トラッキング方向の溝の有無による反射光の強弱 を光検出器で受光し, その位相検出を行うことで, 高 精度トラック位置制御を行う。

\section{$2.3 \mathrm{LS}-120$ ドライブの特徵}

LS-120 ドライブの特徵は, 連続光サーボ方式の他 k,

• 高線記録密度 $(33.6 \mathrm{KFCI})$

・薄型メタル塗布媒体を採用

・高トラック密度 (2490 TPI)

・ゾーンビットレーコーディングの採用

にある。

\section{4 完全下位互換性}

完全下位互換性の秘密は, 磁気へッド構造にあ る ${ }^{3)}$. $120 \mathrm{MB}$ 用として両 MIG コアと，1 MB，2 MB リード/ライト用多結晶フェライトコアとを，「コ」
の字型セラミックスライダに埋め込み, 融着ガラスで 固定した，「デュアルギャップ」ヘッドを採用した．

\section{3. 各種ディスクドライブとの比較}

ZIP ドライブ等のセクタサーボ方式ドライブでは, 専用のサーボフォーマッ夕が必要である。一方，LS120 ドライブは, 自己フォーマットできる。 また，連 続光サーボを採用していることから，メディアの偏芯 許容性はセクタサーボに比べて大きい。さらに，ディ スクの磁性層はメタル塗布媒体であること, 形状も 3.5 インチ標準ディスクであることから，LS-120 デ ィスクの単価は, 他のメディアと比較して極めて安く できる，LS-120 ドライブは，1インチハイトである こと，およびATAPIをサポートしていることから， 従来の FDD との置き換えが容易である。インストー ルコストは不要である。

\section{4. 今後の製品展開}

ホストインタフェースとして ATAPI をサポートし た。互換性と信頼性を維持し，コストダウンを図る。 さらに,ノートブック対応薄型 FDD を開発中であ る.

今後, ドライブは, 当社の他に, 三菱電機も参入 し，メディアもイメーションの他に日立マクセルも参 入し、コンピュータメーカとともにポスト FDの業界 標準化を図る。

(1996 年 6 月 26 日受付)

\section{〔参 考 文 献〕}

1）平中：“LS-120 ドライブのテクニック”，エレクトロニク ス, 1 月号, pp. 24-25, オーム社 (1996)

2) Jim Goldin: "An Introduction to the Insite 325 Floptical Disk Drive”, SPIE Vol. 1078, Optical Data Storage Topical Meeting, pp. 71-79 (1989)

3）山本, 顧, 平中：“120 MB FDD 完全下位互換磁気ヘッド”, 信学技報, MR 95-68 (1995)

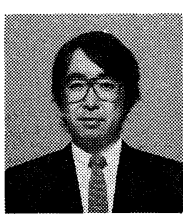

当中妿 弘引ち 1981 年, 九州大学大学院工 学部応用理学専攻修士課程修了. 同年, (株) 富士通研究所に入社. 薄膜トランジス夕の研 究開発に従事. 1991 年, 同社退社. 1991 年, 松下寿電子工業(株)に入社. 以来, FDD の 高密度磁気記録の研究開発に従事. 現在, 同 社情報機器開発センターに勤務. 工学博士。 